\title{
Palynomorphs and Oribatid Mites-From the Denwa Formation, Satpura Basin, Madhya Pradesh, India
}

\author{
Vijaya, Srikanta Murthy \\ Birbal Sahni Institute of Palaeobotany, Lucknow, India \\ Email: murthy_srikanta@yahoo.com
}

Received June 22, 2011; revised September 7, 2011; accepted November 15, 2011

\begin{abstract}
Palynological investigation of the Denwa Formation exposed along Denwa river succession at Saptadara picnic point near village Jhirpa, Satpura Basin, Madhya Pradesh, has revealed the presence of spore-pollen, fungal remains and Oribatid mites. Here, the mites are on record for the first time. Presence of fungal remains strongly depicts the prevalence of a very humid climate with high temperature and rainfall in the region. Poor occurrence of spore-pollen restricts the age determination of the studied section; hence, its age assessment is relative. Thus, an over-view of spore-pollen along with dinocysts and insects reported earlier from the subsurface strata comprising Denwa Formation, from other two localities in the nearby area of village Anhoni, is dealt herein, and that had inferred an age - range from Carnian to Rhaetic for the palynoflora and fauna.
\end{abstract}

Keywords: Spore-Pollen; Fungal Remains; Oribatid Mites; Denwa Formation; Upper Triassic

\section{Introduction}

Satpura Basin is the western most Gondwana Basin among Gondwana basins in India that covers an area of 12,000 sq $\mathrm{km}$ (Figure 1). It is rhomb-shaped and elongated in ENE-WSW direction. The basin is situated in between Son-Narmada south fault in the North and Tan-shear in the South. The Gondwana sequence in this basin starts from Early Permian (Talchir Formation) to Lower Cretaceous (Jabalpur Formation). The Precambrian rocks belonging to Sausar Group occur as the basement of the Satpura Basin. The Denwa Formation occupies the middle unit of the Mahadeva Group in the Satpura Basin, Madhya Pradesh [1]. It is overlaid by Bagra conglomerate and underlain by the Pachmarhi Formation. The Denwa beds are charecterised by red mudstones and subordinate yellow sandstones and are named by [1] to north of Pachmarhi plateau, Madhya Pradesh.

The palynological studies had already been done in the Permian and Triassic successions in scattered areas in the Satpura Basin [2-7]. Moreover, data including the palynomorphs, dinocysts and insect remains from the subsurface is on record only from Denwa Formation, Upper Triassic $[8,9]$.

Nandi [10] was pioneer worker studied palynologically from the subsurface carbonaceous sediments (borecore ANH-1) at Anhoni village and that is dated Carnian to Norian in age. Lately, the spore-pollen dinocysts and insects, have also been reported from the sediments ex- posed in an artesian well, south of Anhoni village, and that had suggested Norian to Rhaetian age $[8,9,11]$.

Fossil fungal remains in the studied sedimentary deposits provide significant proxy records for palaeoenvironmental reconstruction, along with spores-pollen and megafloral remains. However, the utility of fungal remains/ spores in palynostratigraphy of the deposits is rather uncertain, as most of the fungal spore exhibits a wider distribution in the geological time that is from Precambrian to Recent $[6,12]$.

Present investigation in the exposed section along Denwa River succession in study area (Figure 1) has provided additional information about the fungal remains, and fossil remains of a different kind of organism that is Oribatid mites. Although, the mites in fossil records are from middle Lower Devonian deposits [13-16], but there is a "hiatus" until the mites began to formally described in the mid Mesozoic.

\section{Geology of the Area}

In the study area (Figure 1), the beds charecterised by red mudstones and sub-ordinate yellow sandstones in the Denwa River, are named Denwa Formation [1], that is in the north of Pachmarhi plateau, Madhya Pradesh. The Denwa Formation is middle unit of Mahadeva Group; it is overlain by the Pachmari Formation and underlain by the Bagra Formation (Table 1). Denwa Formation comprises mainly alternating beds of sandstone and varie- 


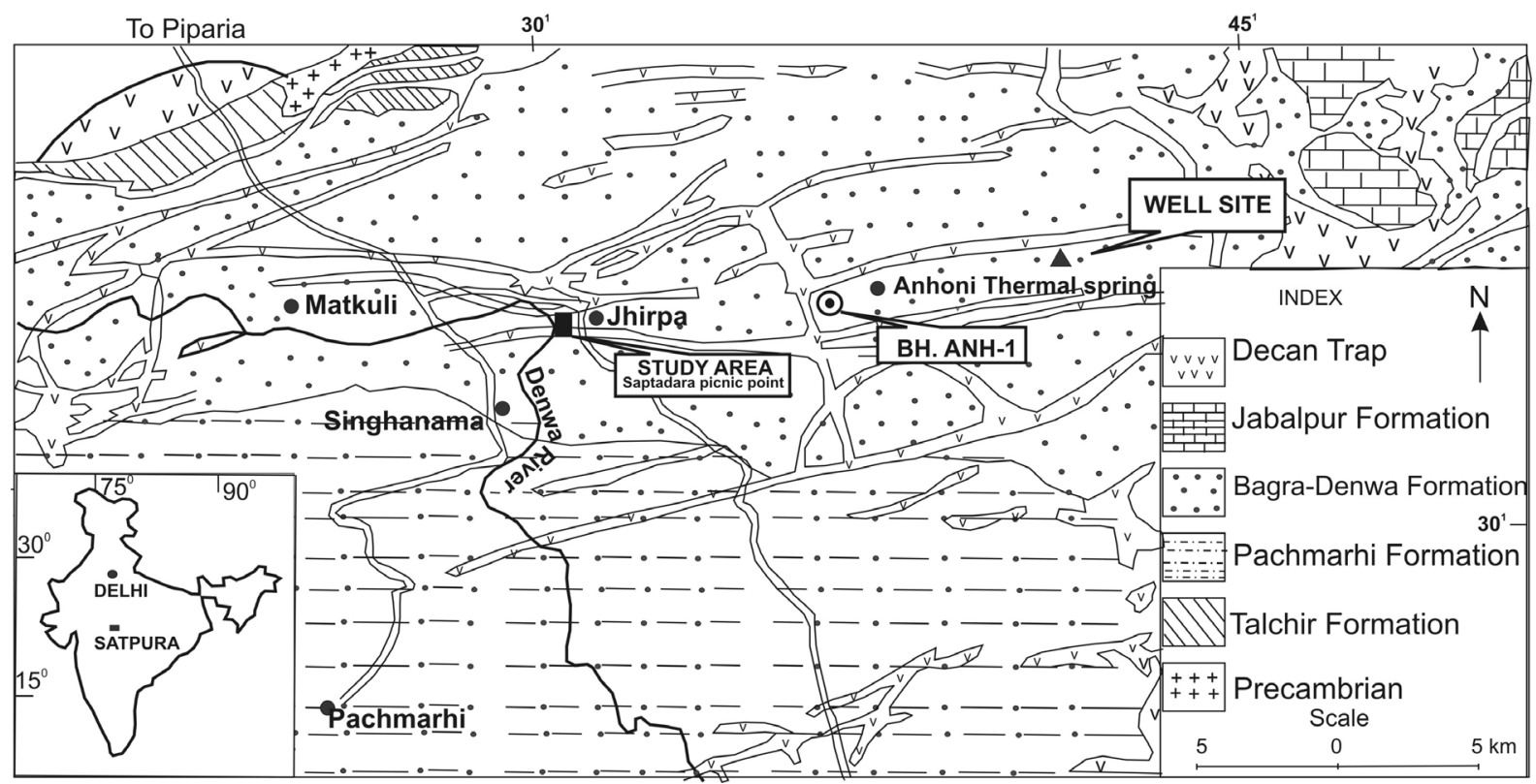

Figure 1. The geological map of Satpura Basin (in Nandi 1996, p. 80) showing three locations of samples-present study ( $\square$ ), Nandi $1994(\odot)$, and Kumar $2000(\Delta)$.

Table 1. Generalised lithostratigraphy in the Satpura Basin, Madhya Pradesh.

\begin{tabular}{|c|c|c|}
\hline Age & Formation & Lithology \\
\hline Lower Cretaceous & Bagra & Conglomerate, pebbly sandstone, red mudstone, abundant calcareous nodules \\
\hline $\begin{array}{l}\text { Upper part of Lower } \\
\text { Triassic to middle Triassic }\end{array}$ & Denwa & Soft variegated clays interbeded with sandstone bands, conglomerate at place \\
\hline Lower Triassic & Pachmarhi & $\begin{array}{l}\text { Very coarse sandstone with minor grey/red mudstone. multi-storey sandstone with } \\
\text { large compound bed forms }\end{array}$ \\
\hline
\end{tabular}

gated clays which are always calcarious and contain numerous calcarious nodules. And, this display a wide range of colours between green red and buff, the red being most characteristic [17-19] and [20]. Therefore, it is believed that the Pachmarhi, Denwa and Bagra formations grade into one-another laterally due to facies variation.

The Denwa Formation consists of three successive lithological units. The basal unit occurring just above the Pachmarhi Formation is sand dominated and poorly fossiliferous. The middle unit, consisting of violet mudstone alternating with white to greenish calcareous, fine to medium grained sandstone, has proved fossiliferous. The upper part comprises brick red mudstone, subordinate white sandstone and peloidal calcirudite [21].

\section{Material and Methods}

The rock samples for present study have been collected from Denwa river bank, Saptadara picnic point $\left(22^{\circ} 35^{\prime} 4^{\prime \prime}\right.$ $\left.\mathrm{N} / 78^{\circ} 30^{\prime} 15.1^{\prime \prime} \mathrm{E}\right)$ near village Jhirpa (Figure 1). The seventeen samples comprised of buff-half white shale, purple claystone, siltstone, khaki-green claystone and arenaceous sandstones facies (Figure 2). From these rock samples, only twelve samples have proved productive in the spore-pollen, fungal remains and Oribatid mites (Table 2).

The rock samples are processed by standard maceration technique, that is 50 gms of sediments crushed, were first treated with $40 \%$ Hydrofluoric acid for 3 - 4 days (to remove silica material), and then followed by Nitric acid for 5 days (digestion of humic matter). Further to this, treated with $10 \%$ potassium hydroxide to release the humus. The maceral, were then mounted in polyvinyl alcohol and Canada balsam for each sample and five slides were prepared. Microscopic observation (Olympus BX61 model) is done from each sample (Table 2) at species level for microfloral analysis, and the species identified are listed in Table 3.

\section{Observations}

Among the Seventeen samples (Table 2), spores and pollen are recovered in samples SPD-3, 4, 8, 10, 11 and 12; but these are less in numbers. The productive residues contain an abundance of fungal remains in samples SPD-1, 2, 3, 4, 8, 10, 11, 12, 13 and 14. Besides, Oribatid mites are recovered only in two samples SPD -8 and 12 . Other remaining elements include wood tissues and root hairs in samples SPD - 2, 3, 15 and 17. Most of these elements are 
Table 2. Yield of spore-pollen, fungal remains, and oribatid mites from river section, Denwa formation near Saptadara picnic point, Satpura Basin.

\begin{tabular}{lll}
\hline Sample No & Lithology & Remarks \\
\hline SPD-1 & Buff half white shale & Palynomorphs absent, Fungal remains rare \\
SPD-2 & Arenaceous sandstone & Fungal remains fair. Woody tissues present \\
SPD-3 & Arenaceous sandstone & Fungal remains rich, Palynomorphs rare, Wood tissues present \\
SPD-4 & Arenaceous sandstone & Fungal remains rare, palynomorphs rare, \\
SPD-5 & Arenaceous sandstone & Unproductive \\
SPD-6 & Purple clay stone & Unproductive \\
SPD-7 & Purple clay stone & Unproductive \\
SPD-8 & Purple clay stone & Palynomorphs rich, Fungal remains rich and Oribatid mites rare \\
SPD-9 & Purple clay stone & Unproductive \\
SPD-10 & Purple clay stone & Palynomorphs rare, Fungal remains rich \\
SPD-11 & Siltstone & Fungal remains rare, Palynomorphs rare \\
SPD-12 & Siltstone & Fungal remains rich, Oribatid mites rich, Palynomorphs rare \\
SPD-13 & Siltstone & Fungal remains medium \\
SPD-14 & Purple clay stone & Fungal remains rare \\
SPD-15 & Siltstone & Wood tissues \\
SPD-16 & Purple-reddish clay stone & Unproductive \\
SPD-17 & Purple-reddish clay stone & Wood tissues and root hairs \\
\hline
\end{tabular}

Table 3. Occurrences of spore-pollen species taxa in the adjacent localities of village Anhoni and Jhirpa in Satpura Basin.

\begin{tabular}{|c|c|c|c|}
\hline Palynotaxa & Out-crop (Present study) & Well-section (Kumar 2000) & B.H. ANH-1 (Nandi 1994) \\
\hline Haradisporites mineri & + & + & \\
\hline Haradisporites scabratus & & + & \\
\hline Osmundacidites sp. & & + & + \\
\hline Dictyophyllidites mortonii & & + & + \\
\hline Monolites anhoniensis & & + & \\
\hline Alisporites indicus & + & + & + \\
\hline Brachysaccus ovalis & & + & + \\
\hline Brachysaccus indicus & + & & \\
\hline Falcisporites australis & & + & \\
\hline \multicolumn{4}{|l|}{ Falcisporites nidpurensis } \\
\hline Falcisporites stabilis & + & & + \\
\hline Krempipollenites indicus & + & + & \\
\hline Minutosaccus crenulatus & + & + & + \\
\hline \multicolumn{4}{|l|}{ Minutosaccus maedleri } \\
\hline Samaropollenites speciosus & + & + & + \\
\hline Satsangisaccites triassicus & + & + & \\
\hline Satsangisaccites royii & + & & + \\
\hline Scheuringipollenites tentulus & + & + & \\
\hline Staurosaccites minutus & & + & + \\
\hline Arcuatipollenites ovatus & & + & \\
\hline Arcuatipollenites pellucidus & & & + \\
\hline Callialasporites sp. & & + & \\
\hline
\end{tabular}




\section{Continued}

Cycadopites cf stonei

Corollina $c f$. simplex

Laricoidites sp

Aratrisporites fischeri

Rimaesporites potoniei

Denwasporites

Convertubisporites

Cyclogranisporites

Cyathidites

Verrucosisporites kazigaonensis

Podocarpidites

Vitreisporites savitrii

Ashmoripollis reducta

Chordasporites sp.

Infernopollenites

Nidipollenites monoletus

Uvaesporites

Camerosporites

Tethysispora

Dictyotriletes

Lundbladispora

Densoisporites

Convolutispora

Foraminisporis

Converrucosisporites

Guttatisporites

Playfordiaspora

Polycingulatisporites

Lapposisporites

Accinctisporites

Nidipollenites

Lueckisporites

Podocarpidites

Sahnites punchetensis

Ringosporites

Todisporites

Leschikisporis

Oribatid Mites

Dinoflagillate cysts

Fungal remains

Rhizomaspora

Guttulapollenites hannonicus

Faunipollenites varius

Striatopodocarpites dubrajpurensis

Striatites cancellatus

Protohaploxypinus sp.

Striatopodocarpites

(n)

\section{$+$}

$+$

$+$

$+$

$+$

$+$

$+$

$+$

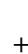

$+$

$+$

$+$

$+$

$+$

$+$

$+$

$+$
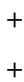

$+++$

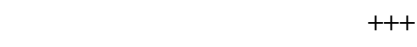

$+\quad+$

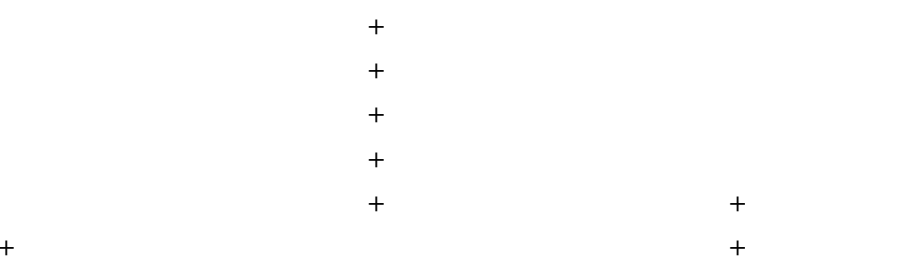




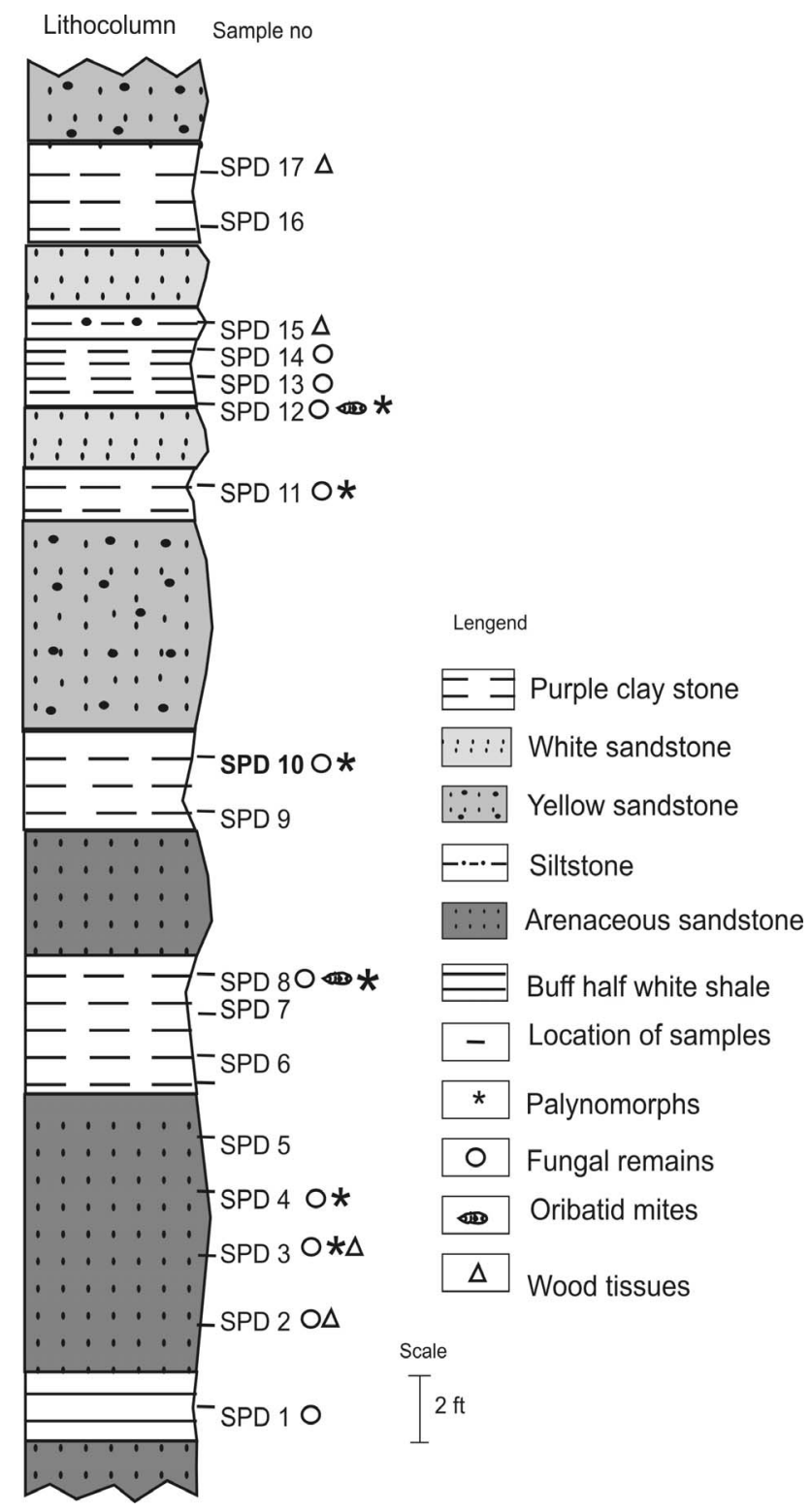

Figure 2. Lithological column along with the sample details. The productive samples are marked with symbols. * = only spore-pollen; $\bullet=$ Fungal remains; $\mathbb{D}=$ Oribatid Mites; $\triangle$ = woody matter.

vaguely structured, not identifiable and the preservation of specimens makes specific determinations difficult. The spore-pollen and fungal taxa identified are given in Tables 3, 4; and illustrated in Figures 3, 4 .

\subsection{Spore-Pollen}

In the facies comprising arenaceous sandstones, claystones and siltstones, the spore-pollen are very poor. The assemblage contains non-striate bisaccate pollen Samaropollenites speciosus, Brachysaccus indicus, Scheuringipollenites sp., Alisporites opii, Krempipollenites in-
Table 4. List of Fungal spores recovered from present study.

\begin{tabular}{cc}
\hline 1 & Alternaria \\
2 & Tetraploa \\
3 & Curvularia \\
4 & Nigrospora \\
5 & Helminthosporium \\
6 & Glomus \\
7 & Entophlyctis \\
8 & Microthyrium \\
9 & cf. Microthyrites \\
10 & Fungal hyphae \\
11 & Fungal fruiting body \\
\hline
\end{tabular}

dicus, Satsangisaccites nidpurensis, Falcisporites stabilis, Minutosaccus maedleri, and Nidipollenites monoletus. Trilete spores are few, represented by Convertubisporites variabilis, Cyclogranisporites sp., Denwasporites anhonii, Haradisporites sinuosus and Aratrisporites fischeri (Figure 3).

\subsection{Fungal Remains}

The fungal remains are observed in high amount from the buff coloured shales, arenaceous sandstones, purple claystone and siltstones. The assemblage includes diverse fungal spores-Alternaria, Tetraploa, Curvularia, Nigrospora, Helminthosporium, Glomus, Entophlyctis, Microthyrium, Cf. Microthyrites, etc. and fungal hyphae, etc. of unknown affinities (Figure 4).

\subsection{Oribatid Mites}

Microscopic, elongated, oval, compact, dorso-ventraly, flattened fossil specimens (Figure 4, No. a-d) of Oribatid and Mesostigmatid mites have also been recovered from the claystone. The fossilized mites belong to KingdomAnimalia, Phylum-Arthropoda, Class-Arachnida, OrderSarcoptiformes, Family-Oribatidae [6]. These hard bodied mites with well preserved seletotized skeleton and dark reddish brown in colour are known as beetle mites. The specimens measure $35.4-51.3 \mathrm{~m} \mu$ in length and 17.5 $23.3 \mathrm{~m} \mu$ in width. Their body with two segments is organised into two tagmata - the one Prosoma, cephalothorax (unsegmented) which is fused head and thorax. The other part is opisthosoma (idiosoma), abdomen that is also unsegmented (Figure 4, a-d). The highly seletotized body suggest that these fossil specimens had probably lived on tree bark.

\section{Discussions}

Based on a small number of identified spore-pollen taxa in the presently studied section (Figure 5, Table 2), their 

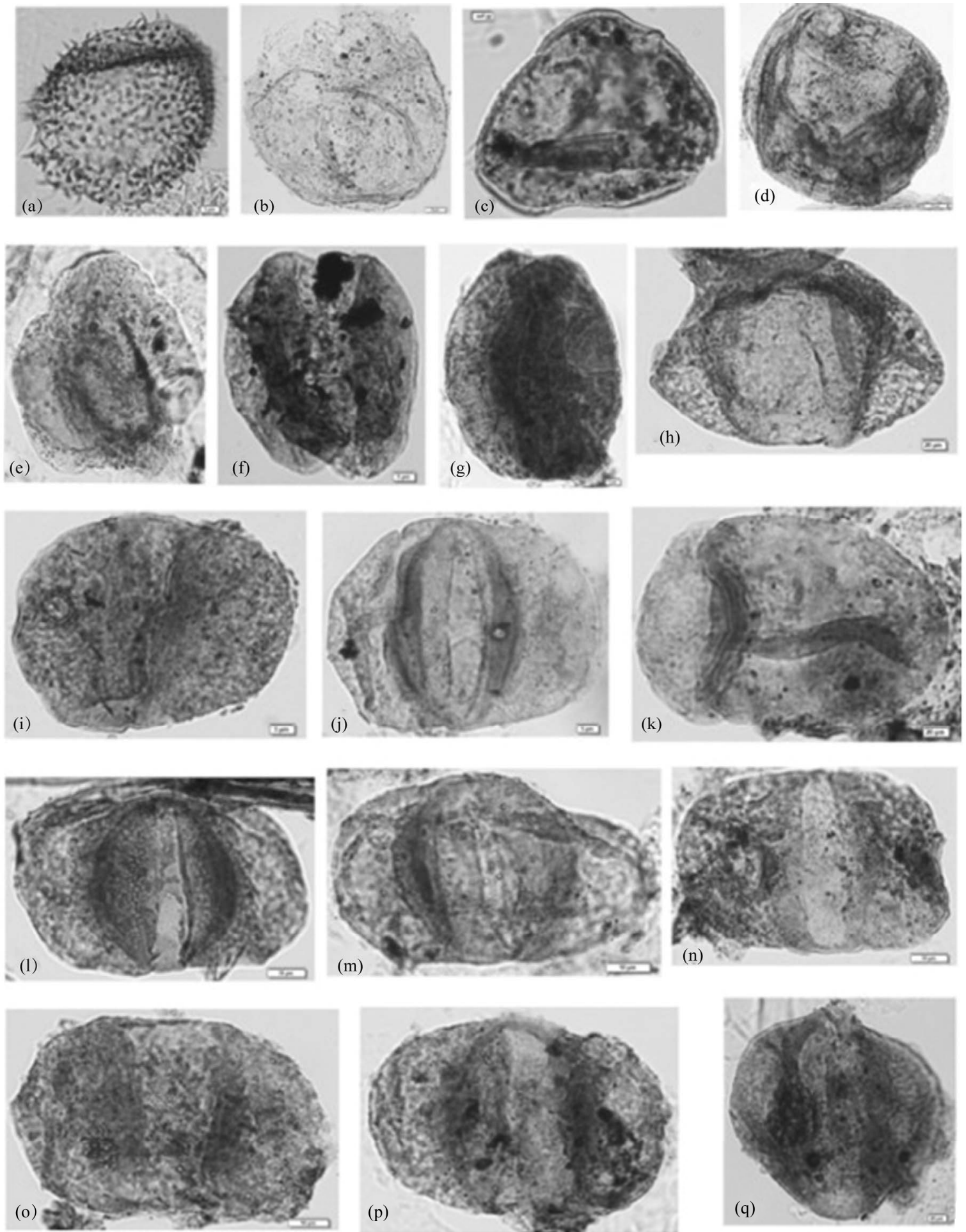

Figure 3. Spore-pollen identified from Denwa River section near village Jhirpa in Denwa Formation (All figures $\times 500$ ca): (a) Convertubisporites variabillis Kumaran and Maheshwari 1980; (b) Cyclogranisporites sp.; (c) Denwasporites anhonii Kumar 1999; (d) Haradisporites sinuosus Kumar 1973; (e) Samaropollenites speciosus Goubin 1965; (f) Brachysaccus indicus Kumaran and Maheshwari 1980; (g) Brachysaccus indicus Kumaran and Maheshwari 1980; (h) Krempipollenites indicus Tiwari and Vijaya 1995; (i) Scheuringipollenites sp.; (j) Nidipollenites monoletus Bharadwaj and Tiwari 1969; (k) Chordasporites austrauliensis de Jersey 1962; (l) Satsangisaccites nidpurensis Bharadwaj and Srivastava 1962; (m) Satsangipollenites sp.; (n) Satsangipollenites nidpurensis Bharadwaj and Srivastava 1962; (o) Falcipollenites strabilis Balme 1970; (p) Alisporites opii Daugherty 1971; (q) Minutosaccus maedleri Kumaran and Maheshwari 1970. 

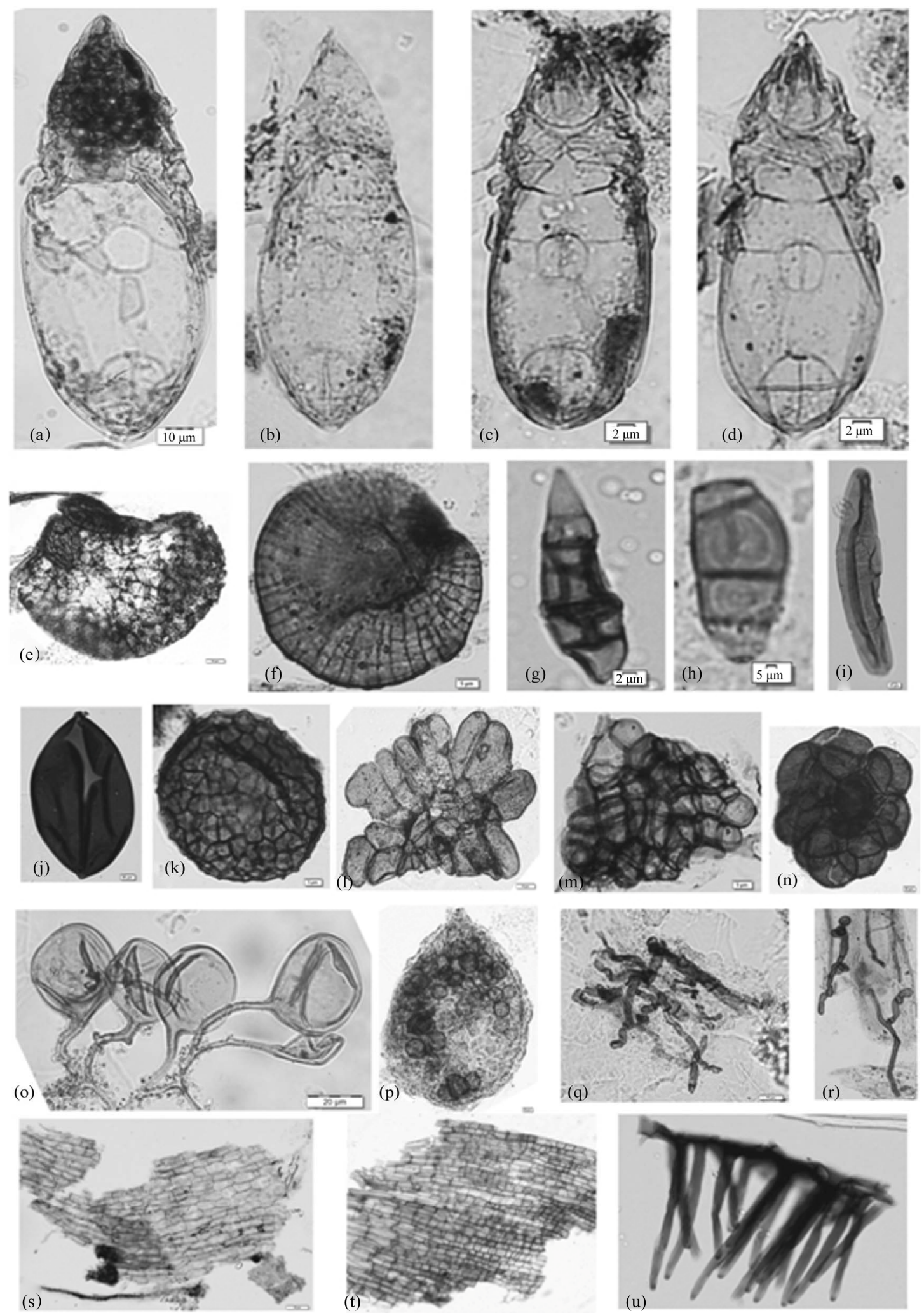

Figure 4. All figures $\times 500$ ca (a)-(d) Oribatid Mites; (e) cf. Microthyrites; (f) Microthyrium; (g) Alternaria; (h) Curvularia; (i) Helminthsporium; (j) Ascospore; (k) Nigrospora; (l) Fungal fruiting body type-I (cf. Cleistothecium); (m) Fungal body type-II; (n) Fungal body type-III; (o) Glomus; (p) Fungal fruiting body with spore type-IV; (q) Fugal mycellium; (r) Hype with Chlamydospore (s) and (t) Wood tissues (u) Root hairs; identified from Denwa River section near village Jhirpa in Denwa Formation, Satpura Basin. 


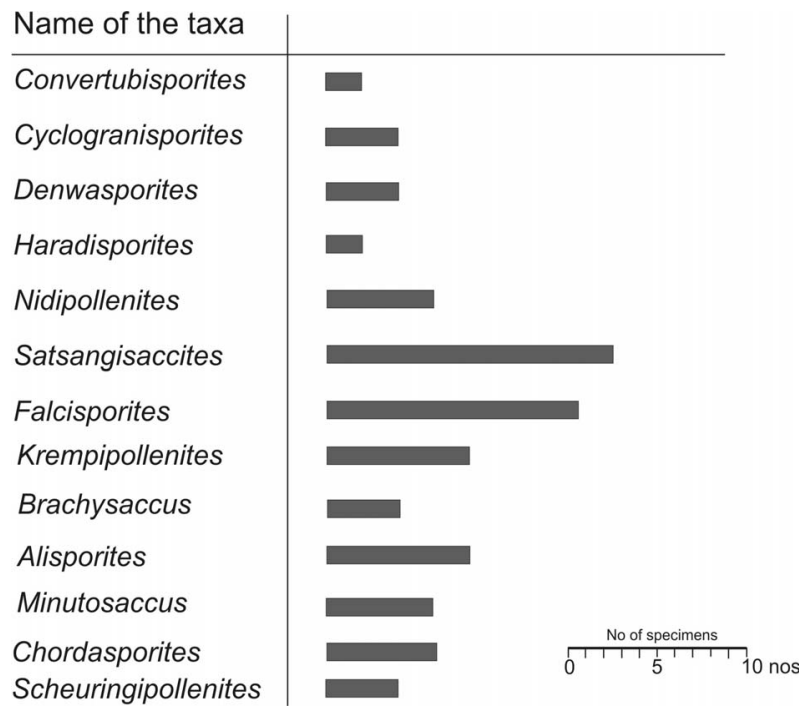

Figure 5. Relative occurrence of spore-pollen taxa in productive samples in the present studied section in Saptadara picnic point near village Jhirpa, Satpura Basin.

paucity and poor preservation, do not allow the precise dating. The age assessment of the studied section is relative as compared with the palynological data available from the other two localities in the nearby areas of village Anhoni (Figure 1, [10,11]). For comparison, a relative count about the spore-pollen taxa and their species from the other two localities has been given in Table 3 and Figure 6.

A rich spore-pollen assemblage is reported from borecore ANH-1 (650.00 m deep, drilled in the south of village Anhoni). Here, the quantitative and qualitative assessment of the palynoassemblage zones I and II, show an abundance of non-striate bisaccate pollen. Moreover, the presence of key-taxa-Polycingulatisporites, Uvaesporites, Camerosporites, Convolutispora, Foraminisporis, Aratrisporites along with Infernopollenites, Staurosaccites, and Brachysaccus had suggested Carnian to Norian age for the studied strata [20]; p. 79. However, the present assemblage is not so diversified. Henceforth, very limited possibility of comparison exists with the two palynoassemblages that is from borehole ANH-1 and the present one as is evident from Table 3 and Figure 6.

Moreover, the palynoassemblages known from an artisian well-section near Anhoni village [10], contain an abundance of non-striate along with striate bisaccate pollen. While these taxa are very low in counts in the present assemblage (Table 3). Apart from this, dominance of dinocysts had also been reported in the well-section [8], which are lacking in the present assemblage. Therefore, similarity between the two assemblages might be drawn only in the broader aspect (Table 3, Figure 6).

Besides this, there are many other palynoassemblages on record from the Upper Triassic horizons as discussed

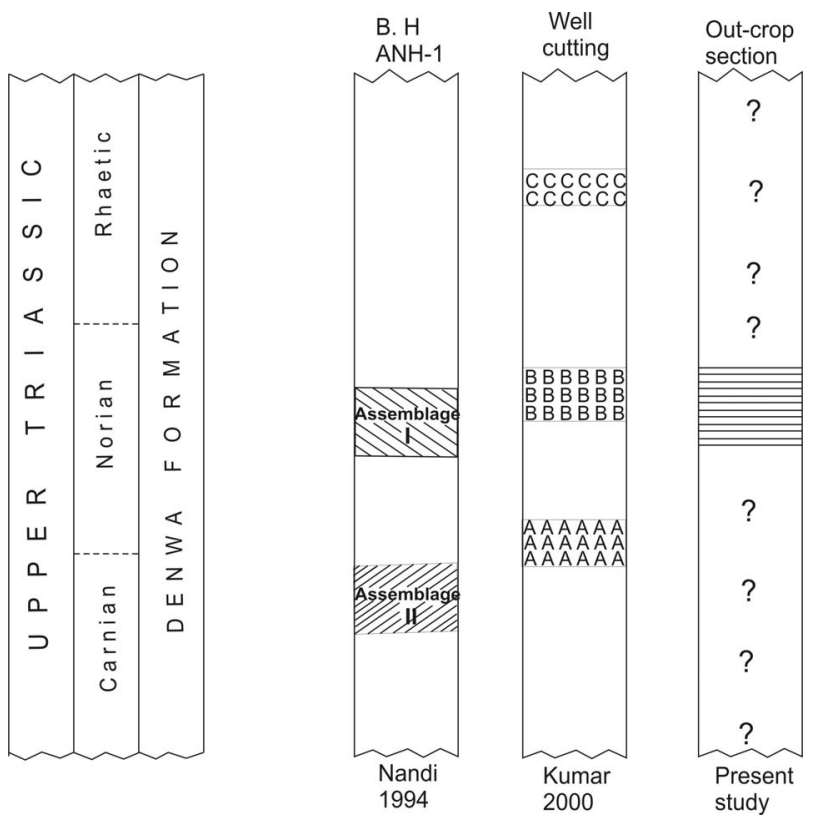

Figure 6. Relative placement of palynoassemblage identified in the present section with those on record from the two adjoining areas near village Anhoni, Satpura Basin. Occurrence of Callialasporites in the assemblage-II infers an younger age to the strata in well-cutting (Kumar, P. 2000).

in [20], p. 96; [7], pp. 15-16 and [22], pp. 97-98. But, the present assemblage in having paucity of the spore-pollen taxa can only be placed within broader time-span of the Late Triassic that had already been determined previously for Denwa Formation (Figure 7). Furthermore, the placement of these assemblages has been assessed with those known from Upper Triassic successions in India and Australia (Figure 8).

In the Satpura Gondwana Basin, sediments comprised a series of lakes in fluviatile complex which were never very deep [17]. Denwa clays vary in colours from that green, red, mottled red, white and buff, but the red ones are most chereterstic $[17,23]$.

The strata representing the Denwa Formation in the nearby villages Jhirpa and Anhoni, including the three locations (Figure 1), has an estimated thickness of about $650.00 \mathrm{~m}$. And it is divided into many units of lithofaciespurple red clays, claystone pebbly and arenaceous sandstone, and carbonaceous buff shales; that are deposited in a variety of environments. The spore-pollen occurs mainly in carbonaceous shales, khaki-green clay, and purple-red claystone. But their recovery has happened relatively very less from that in carbonaceous facies to purple-red facies (present study). That evidences the impact of depositional set-up on the quantitative presentation as well as on their state of preservation.

Ten out of seventeen samples investigated from Denwa river section, Satpura Basin, Madhya Pradesh, have shown a good assemblage of diverse fungal remains com- 


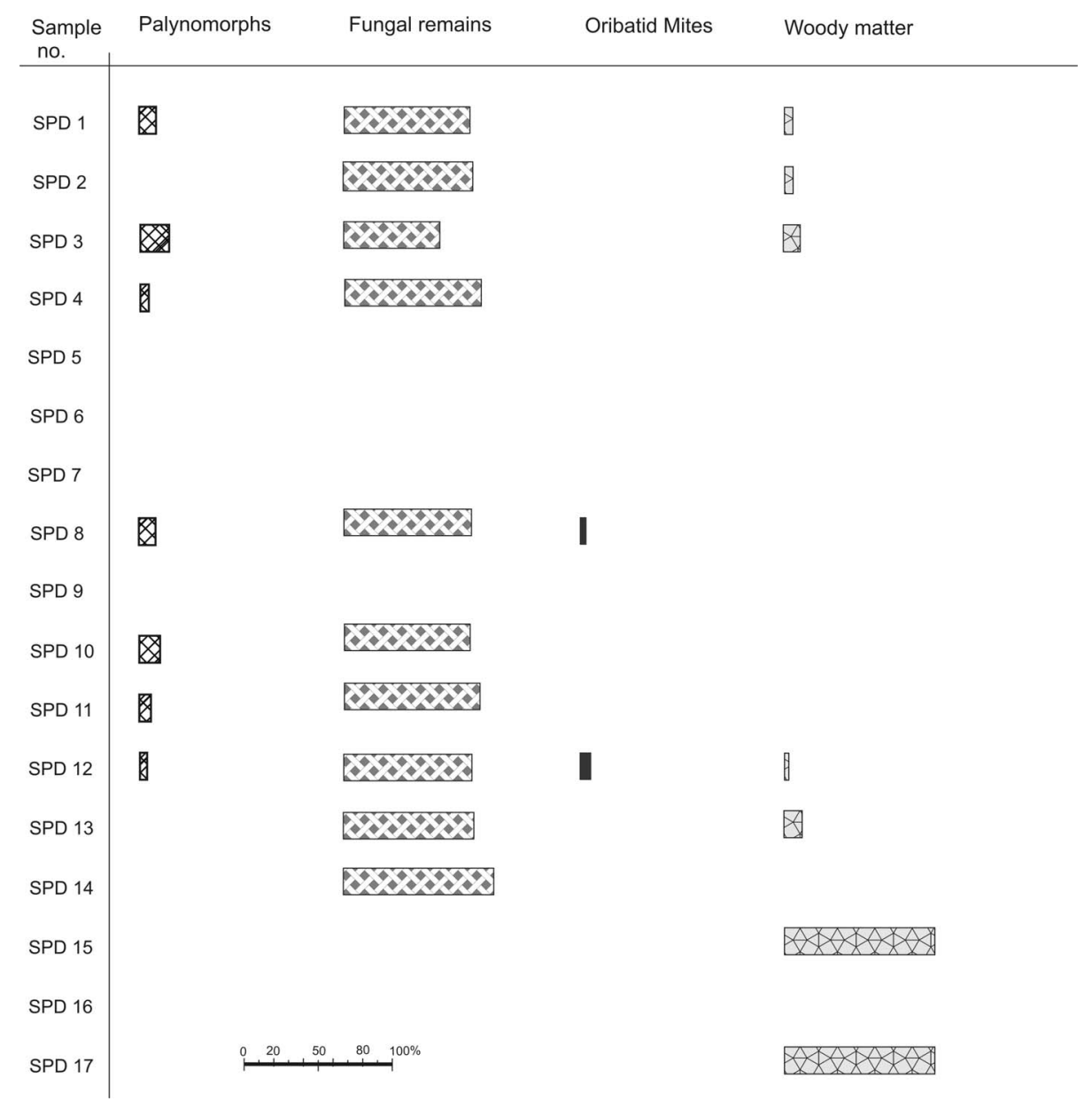

Figure 7. Relative occurrences of spore-pollen, fungal remains, Oribatid Mites and woody matter are displayed in the productive samples in the presently studied section, Saptadara picnic point near village Jhirpa, Satpura Basin.

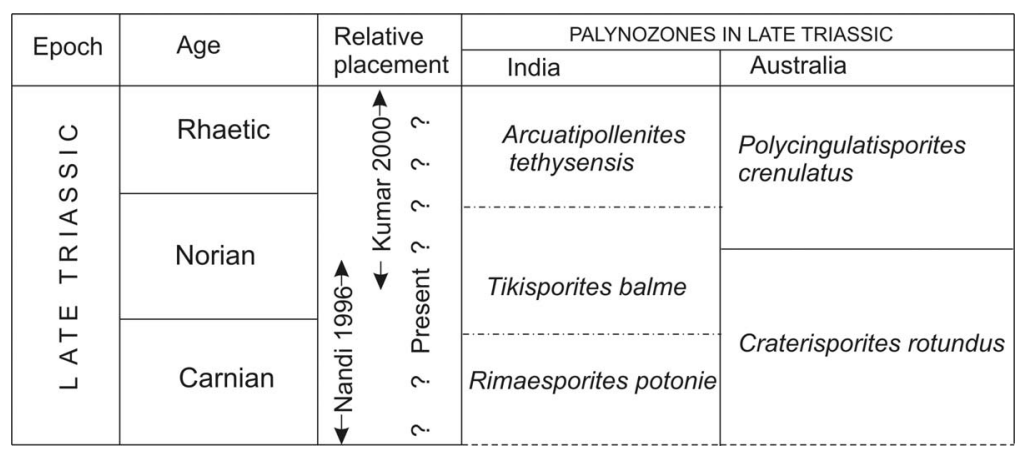

Figure 8. Stratigraphic placement of the spore-pollen assemblage (present study) in the Late Triassic sequence in India and Australia.

prising nine identified genera viz. identified extant genera viz., Alternaria, Tetraploa, Curvularia, Nigrospora, Helminthosporium, Torula, Glomus, Entophlyctis and Microthyrium, one form genus cf. Microthyrites and 8 fungal remains in the forms of such as ascospores, fungal spore type, hyphae, fungal fruiting body, etc. of unknown affinities.

The retrieval of parasitic fungi viz., Alternaria, Tetra- lpoa, Nigrospora, Helminthsporium and Curvularia of herbaceous plants suggests the presence of plenty of undergrowth around the investigating site owing to the prevailing damp and moist condition during the period of sediment deposition. Further, the sediments seem to be accumulated in a ponding environment as evidenced from the record of aquatic saprophytic fungi Entophlyctis and Glomus, which dwells frequently along the lake margin 
and in the lakes. During the course of sedimentation, the region might have supported thick forest cover as indicated by the considerable encounter of epiphyllous fungi, Microthyrium and cf. Microthyrites, which flourish well presently on the tropical trees. Their presence also strongly depicts the prevalence of a very humid climate with high temperature and rainfall in the region since they require such climatic conditions for their optimal proliferation and dissemination [24].

An overview of the other associated elements (woods and cuticles), which are present in the twelve samples (Figure 7), reveals that sediment deposition in the study area had the impact of high energy flow of the source material. That had major effect on the preservation of these elements. Furthermore, sediments in pockets had yielded - fungal remains, dinoflagellate cysts, and varied types of insects as well as Oribatid mites. Dinocyst assemblage had been reported from the well cutting samples [7], p. 12, which suggest lacustrine environment for Denwa Formation deposits [8], p. 103.

The mites are generally considered as an ancient lineage of chelicerate arthropods but their fossil records are mixed [25]. Acarina or Acari is taxon of arachnids which contains mites and sticks. The mites are truly ubiquitous with unsegmented and non-pediculated abdomen. And the mites also inhabit all kinds of habitat such as aquatic, fresh water, sea water and terrestrial. Hence, no particular environment can be inferred from their presence in the studied section [26].

\section{Conclusions}

From the palynomorphs, other associated plant remains (non palynomorphs) and fossil Oribatid mites recovered from the exposed section along Denwa River, Saptadara picnic point, Denwa Formation, Satpura Basin, it is inferred:

1) Absence of the key taxa-Camerosporites, Foraminisporis, Uvaesporites, Staurosaccites, in the presently studied palynoassemblage do not allow the precise age assessment.

2) Moreover, a age - range between Carnian to Rhaetic is connoted from previous palynological dating in the nearby areas of village Anhoni [1,11].

3) Abundance of fungal spores and bodies depicts the prevalence of moist and damp condition around the investigation site.

4) Very low presentation of spore-pollen and relatively high counts of fungal remains might be due to fluctuation in humidity, water logging and mode of sediment deposition.

5) Record of fossil Oribatid mites in the study area; perhaps indicate a favourable palaeoenvironment for their existence/survival during this particular time span.

\section{Acknowledgements}

Authors are thankful to Dr. N. C. Mehrotra, Director, BSIP, Lucknow for providing working facilities as well as for permission to publish this data.

\section{REFERENCES}

[1] H. B. Medlicott, "Notes on the Satpura Coal Basin," Memoir Geological Survey of India, Vol. 10, 1873, p. 159.

[2] D. C. Bharadwaj, R. S. Tiwari and A. Prakash, "Talchir Mioflora from Northern Satpura Basin, India," Palaeobotanist, Vol. 25, 1978, pp. 62-69.

[3] D. C. Bharadwaj, R. S. Tiwari and A. Prakash, "Palynology of Bijori Formation (Upper Permian) in Satpura Gondwana Basin, India," Palaeobotanist, Vol. 25, 1978, pp. 72-78.

[4] S. C. Srivastava, A. Prakash and O. S. Sarate, "Palynology of the Talchir Formation from Betul Coalfield, Satpura Basin, India," Palaeobotanist, Vol. 37, No. 1, 1989, pp. 81-84.

[5] S. C. Srivastava and O. S. Sarate, "Palynostratigraphy of the Lower Gondwana Sediments from Shobhapur Block, Pathakhera Coalfield, Madhya Pradesh," Palaeobotanist, Vol. 37, No. 1, 1989, pp. 125-133.

[6] B. H. Tiffney and E. S. Barghoorm, "The Fossil Record of the Fungi," Occasional Papers Farlow Herbarium, Harvard University, Vol. 7, 1974, pp. 1-42.

[7] P. Kumar, "Palynodating of Denwa Formation, Satpura Basin, India," Plant Cell Biology Development, Vol. 11, 2000, pp. 9-18.

[8] P. Kumar, "Palynomorphs from Denwa Formation (Late Triassic), Satpura Basin, India," Geophytology, Vol. 29, 2000, pp. 99-104.

[9] P. Kumar and P. Kumar, "Insect Remains from Upper Triassic Sediments of Satpura Basin, India," Current Science, Vol. 76, No. 12, 1999, pp. 1539-1541.

[10] A. Nandi, "Palynological and Palaeontological and Faunal studies of Upper (Mesozoic) Gondwana of Satpura Basin, M.P," Record Geological Survey of India, Vol. 127, No. 6, 1994, pp. 283-284.

[11] P. Kumar, "Permo-Triassic Palynofossils and Depositional Environment in Satpura Basin, Madhy Pradesh," Geophytology, Vol. 25, 1996, pp. 47-54.

[12] K. A. Pirozynski, "Fungal Spores through the Ages-A Mycologist View," Proceeding of IV International Palynological Conference, Lucknow (1976-77), Vol. 1, 1978, pp. 327-330.

[13] H. E. Ewing, “Arachmid Order Acarina," In: F. M. Carpenter, Ed., Insects and Arachmida from Canadian Amber, Geological Series, Vol. 40, 1937, pp. 56-62.

[14] S. Hirst, "On Some Arachmid Remains from the Old Red Sandstone," The Annals and Magazine of Natural History, Vol. 12, Series 9, 1923, pp. 455-474.

[15] G. W. Krantz and D. E. Walter, "A Manual of Acarology," 3rd Edition, Texas Teech University Press, Lubbock, 2009. 
[16] W. L. Magowski, "Fossil Heterostigmatid Mites in Amber-85 Million Years Old an Orthropod Mite Relationship,” In: D. Kropezyaska, J. Boczkek and Tomezyk, Eds., The Acari, Physiological and Ecological Aspects of Acarihist Relationships, Dabor, Warszawa, 1995, pp. 53-58.

[17] H. Crookshank, "Geology of the Northern Slopes of the Satpuras between the Morand and the Sher Rivers," Memoir Geological Survey of India, Vol. 66, No. 2, 1936, pp. 242-272.

[18] C. S. R. Rao, "Coal Resources of Madhya Pradesh and Jammu \& Kashmir," Bulletin Geological Survey of India Series A, No. 45, Coalfields of India III, 1983, pp. 1-204.

[19] M.V. A. Sastry, S. K. Acharya, S. C. Shah, P. P. Satsangi, S. C. Ghosh, P. K. Raha, G. Singh and R. N. Ghosh, "Stratigraphic Lexicon of Gondwana Formation of India," Miscellaneous Publication Geological Survey of India, Vol. 36, 1977, pp. 1-170.

[20] A. Nandi, "Palynodating of Carbonaceous Shale from Denwa Formation, Satpura Basin, M.P., India," IX International Gondwana Sequences, Gondwana Nine, Vol. 1, 1996, pp. 79-87.

[21] S. Bandopadhyay and D. P Senguptha, "Middle Triassic Vertebrate of India," Journal of African Earth Science,
Vol. 29, No. 1, 1999, pp. 233-241. doi:10.1016/S0899-5362(99)00093-7

[22] A. Tripathi and A. K. Raychowdhuri, "Triassic Palynoflora from the Mahuli-Mahersop Area, Singrauli Coalfield (Southern Extension), Sarguja District, Chhattisgarh, India," Journal of the Palaeontological Society of India, Vol. 50, No. 2, 2005, pp. 77-99.

[23] I. B. Singh, "Mineralogical Evidences for Climate Vicissitudes in India during Gondwana Times," Geophytology, Vol. 6, No. 2, 1976, pp. 174-185.

[24] S. Murthy and M. S. Chauhan, "Fungal Remains from the Denwa Formation, Satpura Basin, Madhya Pradesh and Their Palaeoenvironmental Implication," Journal of Indian Association of Sedimentologist, 2011, in press

[25] R. A. Norton, P. M. Bonarno, J. D. Grierson and W. A. Shear, "Oribatid Mite Fossils from a Terrestrial Devonian Deposit near Gilboa, Newyork," Journal of Palaeontology, Vol. 62, No. 2, 1988, pp. 259-269.

[26] S. Murthy and P. Kumar, "Oribatid Mite Remains from Denwa Formation (Late Triassic), Satpura Basin, Madhya Pradesh, India," Journal of Palaeontological Society of India, 2011, in press. 